REGARDS

SUR LEECONOMIE ALLEMANDE

BULLETIN ECONOMIQUE DU CRAC

\section{Regards sur l'économie allemande}

Bulletin économique du CIRAC

$101 \mid 2011$

Varia

\title{
Politique familiale
}

OCDE, Doing Better for Families

\section{(2) OpenEdition}

\section{Journals}

Édition électronique

URL : http://journals.openedition.org/rea/4306

DOI : $10.4000 /$ rea.4306

ISBN : 978-2-8218-0954-3

ISSN : 1965-0787

Éditeur

CIRAC

Édition imprimée

Date de publication : 10 juin 2011

ISSN : 1156-8992

Référence électronique

"Politique familiale », Regards sur l'économie allemande [En ligne], 101 I juin 2011, mis en ligne le 19 septembre 2011, consulté le 22 septembre 2020. URL : http://journals.openedition.org/rea/4306 ; DOI : https://doi.org/10.4000/rea.4306

Ce document a été généré automatiquement le 22 septembre 2020

(c) CIRAC 


\title{
Politique familiale
}

\author{
OCDE, Doing Better for Families
}

\section{RÉFÉRENCE}

OCDE, Doing Better for Families, Editions OCDE, Paris, 2011, 275 p.

1 En sept grands chapitres, ce rapport de l'OCDE offre une comparaison internationale en matière de politique familiale. Il aborde la mutation structurelle des foyers, les dépenses publiques consacrées à la famille, les taux de fertilité, l'emploi parental, la promotion du bien-être infantile, la problématique des parents isolés ainsi que celle des mauvais traitements infligés aux enfants. Assorti de nombreuses données statistiques, ce livre cherche à apporter des réponses quant à l'efficacité des diverses mesures gouvernementales et au rôle de la crise sur le soutien alloué aux familles. (sh) 